Marquette University

e-Publications@Marquette

Spanish Languages and Literatures Research and

Languages, Literatures and Culture Faculty

Publications

Research and Publications

$1-1-2018$

Language Practice and Study Abroad

Todd A. Hernández

Marquette University, todd.hernandez@marquette.edu

Published version. "Language Practice and Study Abroad" in Practice in Second Language Learning. Ed. Christian Jones. Cambridge: Cambridge University Press, 2018. DOI. (C) 2018 Cambridge University Press. Used with permission. 


\title{
8 Language Practice and Study Abroad
}

\author{
Todd A. Hernández
}

The present study measures the impact that pragmatic intervention has when students are exposed to targeted language practice during a six-week study abroad programme in Buenos Aires, Argentina. The intervention had three goals. First, the researcher drew learners' attention to language use and context through discussion about pragmatics and exposure to authentic input. Second, the intervention aimed at making students aware of the pragmatic norms of the target culture, including the appropriate use of communication strategies. The third and final goal was to afford the participants opportunities to engage in what DeKeyser (2007) and others argue are five critical aspects of language practice during study abroad: input, output, interaction, guided reflection and targeted feedback. Results indicated that over time all six students increased their use of targetlike request strategies. Journal entries and interviews with the researcher also revealed that the students became more aware of appropriate target-like request behaviour as a result of the language practice. In their journals and interviews, the students also attributed their pragmatic development to three additional sources: interactions with host families and other native speakers, their participation in service encounter exchanges and the targeted feedback given to them by the researcher. The results suggest that exposure to targeted language practice prior to and during study abroad can facilitate pragmatic learning and, in turn, contribute to a more successful study abroad experience.

\section{Introduction}

Although study abroad is thought to be the ideal environment for developing advanced language competence, some study abroad students do not receive the amount of target language practice that one might expect (Pellegrino 1998; DeKeyser 2007; Kinginger 2008; Bataller 2010). Further, while the expectation is that students will make strong linguistic gains during study abroad, 
previous studies demonstrate that second language (L2) development in this context is not as significant as the foreign language profession once assumed (DeKeyser 2007; Magnan and Back 2007; Kinginger 2008; Hernández 2010). This is particularly the case in short-term study abroad, where the short duration and traditional 'sheltered' structure of the programme may prevent students from adequate integration into their respective host communities (Allen 2010; Hernández 2010, 2016; Castañeda and Zirger 2011). See also Chapter 6 (this volume) for a discussion of this area.

Given the potential limitations of study abroad (e.g. Pellegrino 1998; DeKeyser 2007; Kinginger 2008), a growing number of researchers have begun to advocate providing students with explicit instruction in language and culture strategies prior to and during study abroad (Cohen and Shively 2007; DeKeyser 2007; Shively 2010). This chapter investigates the impact of an intervention aimed at developing the pragmatic competence of six students during a six-week study abroad programme in Buenos Aires, Argentina. The researcher measured the effect of the intervention on the students' request performance and developing awareness of the pragmatic norms of the host culture. The chapter then concludes with a discussion of the positive effects of explicit instruction in maximising target language practice and developing pragmatic competence during study abroad.

\section{Previous Research}

This review of the literature begins with a discussion of requests and then outlines the general pattern of pragmatic development as L2 learners adopt more target-like request behaviour over time. The literature review then transitions to the acquisition of requests during study abroad, and the issue of language practice during study abroad.

\section{Requests}

A request, one of the most common communicative acts, involves one person asking another to perform an action (e.g. provide goods or services, give information or share an object). A request is a face-threatening speech act that tends to benefit the speaker while not providing a benefit to the interlocutor (Brown and Levinson 1987). Making an appropriate request is therefore a significant challenge for L2 learners who must have strong pragmatic competence in order to perform the request without being perceived as rude, offensive or demanding (Kasper and Rose 2002; Usó-Juan 2010). L2 learners thus need to possess both pragmalinguistic and sociopragmatic competence (Canale and Swain 1980). Pragmalinguistic competence is the knowledge about the relationship between target linguistic forms and their functions. 
Sociopragmatic competence is the knowledge about the contextual and social variables that inform pragmalinguistic choices.

Previous studies have identified a general pattern of development as L2 learners move towards adopting more target-like request behaviour (e.g. Kasper and Rose 2002; Félix-Brasdefer 2007). L2 pragmatic development includes a shift from direct to indirect requests, ${ }^{1}$ a reduction in the repetition of routine formulae, less first language (L1) transfer and more frequent use of native-like formulaic routines. Learners also tend to increase their use of internal and external mitigation in their request production. Internal mitigation refers to the strategies that a speaker can use as part of the core request sequence to either attenuate or emphasize the impact of the request. In Spanish, internal mitigation includes use of verbal mitigation with the conditional $(; M e$ prestarías tus apuntes? 'Would you lend me your notes?'), the imperfect past tense (Quería averiguar si ... 'I wanted to find out if ...') and the politeness marker por favor (please). External mitigation refers to the strategies that a speaker can use prior to or after the core request in order to lessen the impact of the request. Examples of external mitigation strategies are presented in Table 8.1.

\section{Acquisition of L2 Requests during Study Abroad}

Study abroad researchers have begun to investigate how L2 learners' request performance evolves over time during a study abroad experience. General findings indicate that students do tend to become somewhat more target-like in their requests after a semester or more of residence (e.g. Cole and Anderson 2001; Barron 2003; Schauer 2007; Shively and Cohen 2008; Bataller 2010; Shively 2011). Cole and Anderson (2001) examined the development of the request strategies of 35 Japanese ESL learners studying abroad for an academic year. A discourse completion test with 10 vignettes was administered as a pre-test and post-test. The Japanese learners shifted from a preference for direct request strategies (e.g. 'Open the door please') to greater use of indirect request strategies (e.g. 'Could you open the door please?'), suggesting a better awareness of target norms at the time of the post-test.

Barron $(2003,2006)$ also used a discourse completion test to investigate the acquisition of requests for 33 advanced L2 German learners during an academic year abroad. Their request production was compared to that of 34 native

1 Authors who have worked on the acquisition of L2 Spanish (e.g. Félix-Brasdefer 2007; Shively 2011) also note that learners may move from indirect to direct requests when the target norms favour direct requests. Shively (2011), for example, found that her study abroad students began to incorporate direct requests (e.g. Ponme un café 'Give me a coffee') into their service encounter exchanges in Spain, a movement towards the target norm. 
Table 8.1 External mitigation strategies

\begin{tabular}{|c|c|c|}
\hline $\begin{array}{l}\text { External mitigation } \\
\text { strategy }\end{array}$ & Example & Function \\
\hline Preparator & $\begin{array}{l}\text { Buenas tardes. Disculpe. ¿Tiene un minuto } \\
\text { profesor? Quería hacerle una pregunta. } \\
\text { Good afternoon. Excuse me. Do you have a } \\
\text { minute professor? I wanted to ask you a } \\
\text { question. }\end{array}$ & $\begin{array}{l}\text { The speaker prepares his } \\
\text { or her hearer for the } \\
\text { request. }\end{array}$ \\
\hline Grounder & $\begin{array}{l}\text { Siento mucho molestarlo, pero estaba } \\
\text { hablando con mis compañeros y a todos } \\
\text { nos resulta un poco difícil seguir lo que } \\
\text { está diciendo en clase. } \\
\text { I hate to bother you, but I was talking with my } \\
\text { classmates and we are all having a difficult } \\
\text { time understanding what you say in class. }\end{array}$ & $\begin{array}{l}\text { The speaker gives } \\
\text { reasons, explanations, } \\
\text { or justifications for his } \\
\text { or her request. }\end{array}$ \\
\hline Disarmer & $\begin{array}{l}\text { Nos encanta su clase y nos parece muy } \\
\text { interesante ... lo que pasa es que a veces } \\
\text { no entendemos todo lo que dice porque } \\
\text { habla un poco rápido para nosotros. } \\
\text { We love your class and we all think that it's } \\
\text { interesting ... but we sometimes don't } \\
\text { understand everything you say because } \\
\text { you speak a bit too fast for us. }\end{array}$ & $\begin{array}{l}\text { The speaker attempts to } \\
\text { remove potential } \\
\text { objections the hearer } \\
\text { might raise with the } \\
\text { request. }\end{array}$ \\
\hline $\begin{array}{l}\text { Imposition } \\
\text { minimiser }\end{array}$ & $\begin{array}{l}\text { Carlos, entiendo que necesitas usar tus } \\
\text { apuntes también. ¿Qué te parece si saco } \\
\text { fotcopias de tus apuntes ahora en el } \\
\text { kiosko y te los devuelvo en } 20 \text { minutos? } \\
\text { Carlos, I understand that you need your notes } \\
\text { also. What do you think if I make } \\
\text { photocopies of your notes at the kiosk and } \\
\text { then return them to you in about } 20 \\
\text { minutes? }\end{array}$ & $\begin{array}{l}\text { The speaker attempts to } \\
\text { reduce the imposition } \\
\text { of the request. }\end{array}$ \\
\hline $\begin{array}{l}\text { Acknowledgement } \\
\text { of imposition }\end{array}$ & $\begin{array}{l}\text { Claro, entiendo que le estoy pidiendo } \\
\text { mucho. } \\
\text { Of course. I understand that I am asking you a } \\
\text { lot. }\end{array}$ & $\begin{array}{l}\text { The speaker } \\
\text { acknowledges that } \\
\text { the request poses an } \\
\text { imposition to the } \\
\text { hearer. }\end{array}$ \\
\hline Appreciation & $\begin{array}{l}\text { Gracias. } \\
\text { Thanks. }\end{array}$ & $\begin{array}{l}\text { The speaker thanks the } \\
\text { hearer. }\end{array}$ \\
\hline
\end{tabular}

speakers of German. The L2 learners increased their discourse structure, use of routine formulae and internal mitigation over time, thus demonstrating greater knowledge of pragmatic norms in German. L1 transfer of request strategies into German was also less frequent at the time of the post-tests. Although the students improved their request production, their use of verbal mitigation 
continued to be viewed as non-target-like. Barron (2003) concluded that L2 learners often do not have sufficient target language practice with native speakers during study abroad that would contribute to more robust L2 pragmatic development.

Schauer $(2004,2007,2009)$ observed a relationship between length of time in the target culture and pragmatic development for nine German learners of English during a study abroad experience in Great Britain. Data were collected at three distinct times using a multimedia task containing 16 request scenarios. Scenarios differed with regard to the status of the interlocutors and the degree of imposition of the request. The author found that the ESL learners all increased their use of target-like internal mitigation by the end of study abroad. Some of the ESL learners, however, continued to use direct request strategies in high-imposition scenarios or in scenarios with higher-status interlocutors. The author attributed the use of direct requests in these contexts to negative L1 transfer. In examining the participants' data, Schauer (2007) concluded that experiences with native speakers, exposure to the L2 and motivation to establish social relationships with host culture members all combine to influence learners' pragmatic development when making requests.

Other studies have concluded that after a semester abroad, L2 learners of French or Spanish also become more target-like in their request performance. Magnan and Back (2006) studied the request strategies of six study abroad participants during a semester in France. The more proficient students became somewhat more target-like in their request behaviour, increasing their use of formal address forms and their use of indirect request strategies. Shively and Cohen (2008) investigated the requests of 67 study abroad learners who spent a semester in a Spanish-speaking country. Pre- and post-test written request production questionnaires indicated that the group improved specific aspects of their request performance, while others remained unchanged. For example, while no patterns of development were observed for external mitigation use, the students increased their internal mitigation with the conditional (e.g. ¿Podría hablar más despacio? 'Could you speak slower?'). A comparison of their request strategies with those of a group of native speakers of Spanish also revealed overuse of the politeness marker por favor in some request scenarios and continued preference for speaker-oriented requests (e.g. ¿Puedo tener una extensión en el informe? 'Can I have an extension on the paper?') rather than more target-like hearer-oriented requests (e.g. ¿Me daría una extensión en el informe? 'Would you give me an extension on the paper?').

Bataller $(2008,2010)$ also found that students became somewhat more target-like in their performance of two service encounter exchanges after a semester of study abroad in Spain. In the first scenario, requesting something to drink, some students reduced their use of speaker-oriented requests, a movement towards the target norm. In the same scenario, some of the students 
also incorporated more instances of target-like internal mitigation into their requests, using the imperfect past tense (e.g. Quería preguntarle si ... 'I wanted to ask you if ...') and the conditional tense (e.g. ¿Me cambiaría estos zapatos? 'Could you exchange these shoes for me?'). Both changes again represented a shift towards more target-like request behaviour. Other features of their request performance, however, remained non-target-like. In the second request scenario, exchanging a pair of shoes without the receipt, the students used non-native-like direct request strategies (e.g. No tengo el ticket pero quiero comprar otros zapatos 'I don't have the receipt but I want to buy another pair of shoes') both before and after study abroad. In both request scenarios, the students also overused the politeness marker por favor to mitigate their requests prior to and after study abroad. Bataller (2010) concluded that some of the students spent most of their time in and outside of class with their American peers. As a result, it might have been more difficult for them to become aware of target-like pragmatic strategies. The author argues that students would benefit from pragmatic instruction during study abroad in order to be made more aware of target language pragmatic features.

In order to enhance study abroad students' L2 pragmatic development, some researchers have begun to examine the impact of pragmatic instruction on the acquisition of requests and other speech acts during study abroad (e.g. Cohen and Shively 2007; Shively 2011). Cohen and Shively (2007) investigated the effect of pragmatic instruction on the request production of students participating in a one-semester programme in a Spanish-speaking country or France. The experimental group received a pre-departure orientation to speech acts and a self-study guidebook on language and culture strategies. The students then engaged in reflection activities about their language use. The control group did not participate in these activities. Although both groups improved their request performance after the semester abroad, the experimental group did not outperform the control group. The authors concluded that the pedagogical intervention might not have been long or intensive enough to have a stronger impact on pragmatic development as measured on the post-tests.

Shively (2011) reported on longitudinal research on service encounters between seven study abroad students and Spanish service providers. The students were given an hour-long orientation about pragmatics and 30 minutes of instruction on pragmatics and speech acts, with the intent of raising their awareness of the relationship between context and language use. During the fifth week of the semester, the students were given 30 minutes of explicit instruction on making requests in Spanish, which also included discussion about service encounters. Naturalistic audio recordings of service encounters taken at the beginning, middle and end of the semester revealed a shift from reliance on speaker-oriented requests (e.g. ¿Puedo tener un café? 'Can I have a coffee?') to greater use of hearer-oriented (e.g. ¿Me das un café? 'Will you 
give me a coffee?') and elliptical (e.g. Un café, por favor 'A coffee, please') requests. The students also adopted more native-like direct request strategies (e.g. Ponme un café 'Give me a coffee'), which are considered appropriate in Spain. Their use of the address terms tú and usted and internal mitigation with the politeness marker por favor, however, did not change during the semester abroad.

In addition to explicit instruction, researchers have also found evidence to support noticing as an important feature in fostering L2 learners' pragmatic development (Shively 2013; Ren 2014). Shively (2013), for example, discovered that service encounter exchanges were effective in drawing learners' attention to important differences between their own non-target-like L2 use and the pragmatic norms of the host culture. Ren (2014) examined the cognitive processes of 20 Chinese learners of English who were studying abroad for one academic year. The students were given eight oral production scenarios to measure their use of refusals. Over time, the students paid more attention to how context influenced their language use. Retrospective verbal reports showed that some of the L2 learners were also able to notice differences between target norms and their own language use.

\section{Language Practice and Study Abroad}

Previous studies suggest that students often do not have adequate target language practice during the study abroad experience to foster significant L2 pragmatic development (Hoffman-Hicks 1999; Bataller 2010; and also Chapter 6 , this volume). At the same time, some researchers argue that students lack adequate awareness of linguistic and culture strategies to make the most of the study abroad environment (Kasper and Rose 2002; Cohen and Shively 2007; DeKeyser 2007; Bataller 2010). This is indeed true for short-term study abroad, where students often find it difficult to access social networks with native speakers (Allen 2010; Hernández 2016). Some students isolate themselves from the host culture and spend most of their time with L1 peers rather than with native speakers (Mendelson 2004; Allen 2010; Hernández, 2016). In addition, previous studies suggest that study abroad students tend not to receive corrective feedback from native speakers about their pragmatic behavior (DuFon 1999; Barron 2003; Shively 2011).

In view of the evidence of inadequate use of language resources during study abroad, several researchers have begun to advocate providing study abroad students with training and instruction in language use strategies. However, although a few studies have examined the impact of pre-departure instruction on L2 pragmatic development (e.g. Cohen and Shively 2007; Shively 2011), no previous scholarship exists that incorporates the use of language practice tasks during a short-term study abroad experience. 
Given this information, the aim of the present study is to measure the impact of targeted language practice on the request behaviour of six students during a six-week study abroad programme in Buenos Aires. Two questions were created to guide the research:

Research Question 1: Do short-term study abroad students become more target-like in their request performance after exposure to language practice both before and during study abroad?

Research Question 2: What do the students' journal entries and interviews reveal about their learning of requests during the short-term study abroad experience?

\section{Methodology}

\section{Study Abroad Participants}

The study abroad group consisted of six undergraduate students (four females and two males) participating in a six-week study abroad programme in Buenos Aires during the summer of 2014. All were native speakers of English from the United States between the ages of 19 and 21. There were no heritage speakers of Spanish. None had previous study abroad experience. Table 8.2 provides further participant information.

During their time abroad, all six students took two three-credit contentbased courses at a private language institute in Buenos Aires: Latin American

Table 8.2 Participant background information

\begin{tabular}{|c|c|c|c|c|c|}
\hline Name & Age & $\begin{array}{l}\text { Academic } \\
\text { status in } \\
\text { fall } 2014\end{array}$ & Academic major & $\begin{array}{l}\text { High } \\
\text { school }\end{array}$ & $\begin{array}{l}\text { Highest college } \\
\text { Spanish taken }\end{array}$ \\
\hline Anna & 19 & Sophomore & Speech Pathology & 4 years & $\begin{array}{l}2 \text { fifth-semester courses in } \\
\text { composition and } \\
\text { conversation }\end{array}$ \\
\hline Patrick & 20 & Junior & $\begin{array}{l}\text { International Affairs } \\
\text { and Spanish }\end{array}$ & 4 years & $\begin{array}{l}2 \text { upper-division Spanish } \\
\text { courses }\end{array}$ \\
\hline Heather & 21 & Senior & $\begin{array}{l}\text { International Affairs } \\
\text { and Spanish }\end{array}$ & 4 years & $\begin{array}{l}4 \text { upper-division Spanish } \\
\text { courses }\end{array}$ \\
\hline Katie & 21 & Senior & Education & 3 years & $\begin{array}{l}2 \text { upper-division Spanish } \\
\text { courses }\end{array}$ \\
\hline Grace & 21 & Senior & $\begin{array}{l}\text { International Affairs } \\
\text { and Spanish }\end{array}$ & 4 years & $\begin{array}{l}3 \text { upper-division Spanish } \\
\text { courses }\end{array}$ \\
\hline Sam & 21 & Senior & International Affairs & 3 years & $\begin{array}{l}2 \text { upper-division Spanish } \\
\text { courses }\end{array}$ \\
\hline
\end{tabular}


culture and introduction to second language acquisition (SLA). Both courses were taught in Spanish and were designed for language learners. The researcher taught the course in SLA. Each course met for eight hours per week for six weeks. Classroom instruction was combined with a series of academiccultural excursions, all of which were conducted in Spanish. All of the participants lived with host families. Two native speakers serving as conversation partners were available to the students throughout their time in Buenos Aires. The students reported sharing these experiences with their partners: watching World Cup 2014 soccer matches, attending movies, concerts and other cultural activities, and going to cafés.

\section{Intervention}

The students received an intervention prior to their departure for Argentina and during their time abroad. The aim of the intervention was threefold. The first goal was to draw learners' attention to the importance of language use and context. The second goal was to make them aware of the pragmatic norms of the target culture and raise their awareness of appropriate language use. The third goal of the intervention was to provide the students with frequent opportunities to participate in what researchers have defined as five critical aspects of language practice during study abroad: input, output, interaction, guided reflection and targeted feedback (DeKeyser 2007). The intervention used in this study appears in Table 8.3.

The intervention was based on an awareness-raising approach to developing pragmatic competence (Martínez-Flor and Usó-Juan 2006; Shively 2010). This model is grounded in the Noticing Hypothesis (Schmidt 2001), which has been discussed in several other chapters in this volume. See, for example, Chapters 1 and 2. In the case of pragmatics, this hypothesis suggests that there must be conscious attention to pragmatic features in the input in order for input to become intake and for learning to occur. In addition to exposure to authentic input, Usó-Juan (2010) states that language learners must have opportunities for collaborative practice and metapragmatic reflection (Swain 2000) that draw their attention to target pragmatic behaviour within a sociocultural context.

During the first part of the language practice intervention, which took place before departure, the researcher discussed with the students how an understanding of pragmatics could contribute to a more successful study abroad experience. Pragmatic instruction consisted of a 90-minute session in which the students were asked to complete a series of readings and activities about pragmatics. The focus of the session was on requests. L2 learners' attention was drawn to the pragmalinguistic strategies and sociopragmatic factors to consider when making a request in Spanish and how these strategies might 


\section{Table 8.3 Language practice intervention}

\section{Part 1. Pre-departure language practice}

\section{Objectives}

Show students how an understanding of pragmatics will contribute to their linguistic and cultural development during their study abroad experience.

Encourage students to consider the relationship between language use and context.

Expose students to authentic input in order to draw their attention to target pragmatic features in context.

Provide students with production practice to transform declarative knowledge of pragmatics into procedural knowledge available for communication with native speakers.

Provide students with targeted feedback to focus their attention on appropriate target language use.

Encourage students to continue to reflect on the relationship between language use and context.

\section{Part 2. Language practice during study} abroad

Students use their knowledge about pragmatic features of host culture to interact with native speakers during study abroad experience.

Provide students with production practice to make progress towards automatisation.

Students are encouraged to compare and contrast their request performance with target norms.

Provide students with targeted feedback to focus their attention on language use in context.

\section{Learning activities}

Explicit instruction: Give students background information about pragmatics and relevance to study abroad.

Requests in Spanish are defined and discussed.

Explicit instruction: Give students pragmalinguistic strategies used when making requests.

Discuss sociopragmatic factors to consider in making requests.

Consider differences between $\mathrm{L} 1$ and $\mathrm{L} 2$ request strategies.

Discuss speaker-oriented versus hearer-oriented requests.

Give students information about use of vos as the second-person personal pronoun in Argentina.

Input practice: Exposure to authentic input consisting of three request scenarios.

Students underline request strategies to encourage noticing and reflection on language use.

Responses are reviewed with the researcher.

Guided communicative practice: Under the guidance of the researcher, the students respond to a written request production questionnaire containing four request scenarios in Spanish.

Communicative practice: The students are given two request scenarios to perform with a classmate.

Feedback: Students receive targeted feedback from the researcher on their request performance.

Students perform five language practice tasks given to them by the researcher.

Using a digital recorder, the students record and transcribe their responses to the five language practice tasks.

Again using a digital recorder, the students ask five native speakers to respond to the same five language tasks.

Students submit transcripts and a reflection for each language practice task.

Feedback: Students receive targeted feedback from the researcher on their request performance for each language task. 
differ from their L1. The researcher also discussed the use of speaker- versus hearer-oriented request strategies and the use of the vos as the second-person singular pronoun in Argentina rather than the informal address form tú used in other regions of the Spanish-speaking world. After discussion of the reading materials, the students received authentic input consisting of three sample request scenarios. The researcher asked them to consider what strategies the Spanish speakers used to make their requests in each scenario. The students were also asked to underline these strategies in order to further draw their attention to language use in context. Responses were reviewed with the researcher. The students then responded to a written request production questionnaire containing four request scenarios in Spanish, shared their responses to the questionnaire with the class and then compared their performance with a group of Spanish speakers from Argentina who had completed the same questionnaire. The students were given two request scenarios to complete with a classmate. After completing the scenarios, the students received feedback from the researcher and the class.

For the second part of the intervention, which took place during study abroad, the students were given five language practice tasks (see Appendix 8.A) designed to encourage social interaction with native speakers, increase their awareness and understanding of the pragmatic norms of the host culture, and provide them with targeted feedback on their pragmatic performance and development. Each of the five tasks represented a request scenario that a student might encounter during study abroad. Using a digital recorder, the students were required to record themselves responding to each of the five request scenarios, and then transcribe their performance for each. In order to compare their pragmatic performance with target norms, the students asked native speakers to respond to the same five scenarios. Responses were transcribed. For each scenario, the students submitted their transcripts with a short reflection about their pragmatic learning.

The researcher provided the students with feedback about their language use in each of the language tasks, attempting to draw their attention to important aspects of pragmatics in the context of their experience in Buenos Aires and the pragmatic norms of the host culture. In addition, during the first three weeks of the programme, the students were asked to again respond to a written request production questionnaire containing three request scenarios. The students shared their responses and also received feedback from the researcher and the class.

\section{Data Collection}

The primary data consist of open role plays that were administered as a pre-test and post-test in order to assess students' request production prior to the 
1. You are at a café in downtown Buenos Aires with a group of friends and want a drink. You approach the counter and order a drink (coffee, tea, or soft drink) from a young man working behind the counter who is about 25 years old. You do not know him.

Figure 8.1 Requesting something to drink

pre-departure intervention and after study abroad. Role plays offer several advantages over more traditional methods of pragmatic data collection, such as written production questionnaires (Kasper and Rose 2002; Félix-Brasdefer 2010; Bataller and Shively 2011). Félix-Brasdefer (2010) suggests that role plays are a more valid representation of authentic spoken language than written discourse completion tasks might be. Unlike discourse completion tasks, which allow participants time to reflect on their responses, role-play data can elicit more spontaneous language production and show discourse features found in natural speech such as intonation, pauses and turn-taking. Further, Bataller and Shively (2011) believe that role-play interactions prompt more negotiation, repetition and external mitigation than written production measures.

Four request scenarios were used in the present study. The first request scenario (Requesting Something to Drink) represented a low-imposition request. The second and third scenarios (Asking a Professor for a Paper Extension and Asking a Professor to Speak Slower) represented mid-imposition requests. The fourth (Exchanging a Bus Ticket) was a higherimposition request. Each participant received a card describing the four scenarios. The first role-play scenario is presented in Figure 8.1; see Appendix 8.B for the remaining three scenarios.

All students interacted with a 32-year-old native Spanish speaker who performed the role of a server in the first scenario and of a professor in the second and third scenarios. He performed the role of a customer service representative in the fourth scenario. The four role plays were also given to 10 native speakers from Buenos Aires, ranging in age from 25 to 30, in order to provide a baseline comparison with the data elicited from the study abroad learners. The researcher and a research assistant coded and quantified the use of semantic formulae in the request scenarios using an adapted version of the Cross-Cultural Speech Act Realization Project (CCSARP) Coding Manual (Blum-Kulka, House and Kasper 1989). Examples are given in Appendix 8.C.

In addition to the data from the four role-play scenarios, a background information questionnaire, journals and interviews were used. For the journals, the students were asked to report on their language learning after the first, third and fifth week of the study abroad programme. The students were allowed to 
write in either Spanish or English. All students wrote in English. At the end of the study abroad experience, the participants also completed a semi-structured interview in English with the researcher. The students were asked to reflect on their language development, describe memorable language learning experiences and discuss which aspects of their time abroad contributed most to their language acquisition.

\section{Data Analysis}

The researcher conducted a case study of six study abroad students in order to provide a comprehensive account of the effects of language practice on their subsequent L2 production. The researcher transcribed the students' pre- and post-test role-play data. Using an adapted version of the 'Cross-Cultural Speech Act Realization Project Coding Manual' (Blum-Kulka, House and Kasper 1989), the researcher and a research assistant then coded and quantified the use of semantic formulae in the role plays. Examples are given in Appendix 8.C. In addition to the quantitative results, qualitative data from the L2 learners' pre- and post-test role-play transcripts provide further insights into the effects of language practice on their L2 pragmatic development. Their journal entries and interviews are additional qualitative data that offer important insights into their pragmatic learning and evolving understanding of pragmatics during study abroad.

\section{Results}

Research Question 1: Do short-term study abroad students become more target-like in their request performance after exposure to language practice both before and during study abroad?

In order to understand how the request performance of the students developed over time, the researcher examined their use of request strategies on the pretest and post-test role plays. The researcher then compared their results with those of a group of 10 native speakers of Spanish from Buenos Aires who completed the same role plays. The findings are presented in Table 8.4, first for internal mitigation, second for external mitigation and then third for request perspective. To remind the reader, internal mitigation refers to the strategies that a speaker can use as part of the core request sequence to either lessen or emphasize the impact of the request. Requests were coded for verbal mitigation and use of the politeness marker por favor.

As shown in Table 8.4, there was a general increase in how much the students used verbal mitigation on the four request scenarios over time. With the exception of the first scenario, Requesting Something to Drink, each 
Table 8.4 Comparison of use of internal mitigation for study abroad students and native speakers of Spanish

\begin{tabular}{|c|c|c|c|}
\hline & \multicolumn{2}{|c|}{ Study abroad students } & \multirow[b]{2}{*}{ Spanish native speakers } \\
\hline & Pre-test & Post-test & \\
\hline & $n(\%)$ & $n(\%)$ & $n(\%)$ \\
\hline \multicolumn{4}{|c|}{ Requesting Something to Drink scenario } \\
\hline \multicolumn{4}{|l|}{ Verbal mitigation: } \\
\hline Conditional & $1(17 \%)$ & $4(67 \%)$ & $2(20 \%)$ \\
\hline Past tense & $0(0 \%)$ & $0(0 \%)$ & $1(10 \%)$ \\
\hline Politeness marker & $6(100 \%)$ & $5(83 \%)$ & $2(20 \%)$ \\
\hline \multicolumn{4}{|c|}{ Paper Extension scenario } \\
\hline \multicolumn{4}{|l|}{ Verbal mitigation: } \\
\hline Conditional & $0(0 \%)$ & $4(67 \%)$ & $3(30 \%)$ \\
\hline Past tense & $0(0 \%)$ & $2(33 \%)$ & $7(70 \%)$ \\
\hline Politeness marker & $1(17 \%)$ & $3(50 \%)$ & $4(30 \%)$ \\
\hline \multicolumn{4}{|c|}{ Slower Speech scenario } \\
\hline \multicolumn{4}{|c|}{ Verbal mitigation: } \\
\hline Conditional & $0(0 \%)$ & $3(50 \%)$ & $2(20 \%)$ \\
\hline Past tense & $0(0 \%)$ & $2(33 \%)$ & $8(80 \%)$ \\
\hline Politeness marker & $1(17 \%)$ & $1(17 \%)$ & $2(20 \%)$ \\
\hline \multicolumn{4}{|c|}{ Exchanging a Bus Ticket scenario } \\
\hline \multicolumn{4}{|l|}{ Verbal mitigation } \\
\hline Conditional & $0(0 \%)$ & $4(67 \%)$ & $3(30 \%)$ \\
\hline Past tense & $0(0 \%)$ & $2(33 \%)$ & $6(60 \%)$ \\
\hline Politeness marker & $0(0 \%)$ & $2(33 \%)$ & $2(20 \%)$ \\
\hline
\end{tabular}

increase was indicative of movement towards target-like pragmatic performance. In the Requesting Something to Drink scenario, one student (17\%) used verbal mitigation on the pre-test, while four $(67 \%)$ did so on the post-test (native speakers $=30 \%$ ). In the Paper Extension and Exchanging a Bus Ticket scenarios, the students also increased their verbal mitigation, going from pretest $(0 \%)$ to six students $(100 \%)$ on the post-test (native speakers $=100 \%)$. In the Slower Speech scenario, while no one used verbal mitigation on the pretest, five students $(83 \%)$ used it on the post-test (native speakers $=100 \%$ ). Examples (1) and (2) demonstrate the shift towards more target-like use of verbal mitigation on the post-tests:

(1) Paper Extension scenario post-test (Katie) Disculpe, profesor Blanco. Quería saber si me podría dar una extensión en mi informe ... para esta semana ...

Excuse me, Professor Blanco. I wanted to know if you could give me an extension on my paper... due this week. 
(2) Slower Speech scenario post-test (Jennifer)

Perdón, doctor García ... ¿Podría hablar usted un poco más despacio para nosotros?

Excuse me, Doctor García ... Could you speak a bit slower for us?

In turning to politeness marker use, results indicated that the students were non-target-like in their use of por favor on the Requesting Something to Drink scenario both before and after study abroad. All six students used por favor on the pre-test compared to five $(83 \%)$ who did so on the post-test. By comparison, the native speakers used the politeness marker $20 \%$ of the time in the same scenario.

In the Paper Extension scenario, however, the students demonstrated a movement towards target-like use of the politeness marker por favor, going from one student $(17 \%)$ on the pre-test to four $(67 \%)$ on the post-test (native speakers $=50 \%$ ). In the Exchanging a Bus Ticket scenario, the group also increased their use of the politeness marker from pre-test $(0 \%)$ to two students $(33 \%)$ on the post-test (native speakers $=20 \%$ ). Their use of the politeness marker on the Slower Speech scenario was similar to the target norm prior to and after study abroad, with one student (17\%) using por favor on the pre-test and one student using it on the post-test (native speakers $=20 \%$ ). Examples (3) and (4) show the use of the politeness marker on the Requesting Something to Drink and the Exchanging a Bus Ticket scenarios:

(3) Requesting Something to Drink scenario pre-test (Anna)

Hola, ¿puedo tener un café, por favor?

$\mathrm{Hi}$, can I have a coffee, please?

(4) Exchanging a Bus Ticket scenario post-test (Sam)

¿Sería posible cambiar mi boleto, por favor?

Would it be possible to change my ticket, please?

External mitigation refers to the strategies that a speaker can use prior to or after the core request in order to lessen the impact of the request (FélixBrasdefer 2007). As shown in Table 8.5, six external mitigation strategies, or supportive moves, were found in the data: Preparator, Grounder, Disarmer, Imposition minimiser, Acknowledgement of imposition, and Appreciation. External mitigation use was not observed in the first request scenario, Requesting Something to Drink, and it therefore does not appear in this section.

As shown in Table 8.5, the students increased their use of external mitigation in three out of the four request scenarios over time. In the Paper Extension scenario, for example, the students increased their use of four strategies from pre-test to post-test. Each increase was suggestive of movement towards target norms. Four students $(67 \%)$ used Disarmer on the pre-test compared with six participants $(100 \%)$ who used it on the post-test (native speakers $=100 \%$ ). 
Table 8.5 Comparison of use of external mitigation for study abroad students and native speakers of Spanish

Study abroad students

\begin{tabular}{|c|c|c|}
\hline Pre-test & Post-test & Spanish native speakers \\
\hline$n(\%)$ & $n(\%)$ & $n(\%)$ \\
\hline
\end{tabular}

Paper Extension scenario

Preparator

$0(0 \%) \quad 4(67 \%) \quad 6(60 \%)$

Grounder

$6(100 \%)$

$6(100 \%) \quad 10(100 \%)$

Disarmer

$4(67 \%)$

$6(100 \%) \quad 10(100 \%)$

Imposition minimiser

$0(0 \%)$

$4(67 \%) \quad 6(60 \%)$

Acknowledgement of imposition

$0(0 \%)$

$5(83 \%)$

$8(80 \%)$

Appreciation

$6(100 \%)$

$6(100 \%)$

$9(90 \%)$

\section{Slower Speech Request scenario}

Preparator

$0(0 \%) \quad 2(33 \%) \quad 7(70 \%)$

Grounder

Disarmer

Imposition minimiser

Acknowledgement of imposition

Appreciation

Exchanging a Bus Ticket scenario

Preparator

$6(100 \%) \quad 6(100 \%) \quad 10(100 \%)$

$1(17 \%) \quad 4(67 \%) \quad 8(80 \%)$

$0(0 \%) \quad 0(0 \%) \quad 3(30 \%)$

$0(0 \%) \quad 3(50 \%) \quad 7(70 \%)$

$5(83 \%) \quad 6(100 \%) \quad 10(100 \%)$

Grounder

$0(0 \%) \quad 2(33 \%) \quad 4(40 \%)$

$4(67 \%) \quad 6(100 \%) \quad 10(100 \%)$

Disarmer

$1(17 \%)$

$4(67 \%) \quad 8(80 \%)$

Imposition minimiser

Acknowledgement of imposition

$0(0 \%)$

$0(0 \%)$

$0(0 \%)$

Appreciation

$1(17 \%)$

$3(50 \%)$

$4(40 \%)$

$6(100 \%) \quad 6(100 \%) \quad 10(100 \%)$

While there was no use at all of Preparator or Imposition minimiser on the pretest, four students $(67 \%)$ used each of these strategies on the post-test (native speakers $=60 \%$ ). A similar pattern of change was seen in the use of Acknowledgement of imposition (pre-test $=0 \%$, post-test $=83 \%$ ). As with the previous strategies, the greater use of Acknowledgement of imposition on the post-test was also consistent with a shift towards target-like pragmatic use (native speakers $=80 \%)$. Pre- and post-test use of Grounder and Appreciation were at $100 \%$ and comparable to that of the native speakers (Grounder $=100 \%$, Appreciation $=90 \%$ ).

In the Slower Speech scenario, the students again increased their use of three external mitigation strategies on the post-test. Although each of these increases represented a movement towards target-like performance, participants' general underuse of these strategies compared to the native speakers still persisted, even at the time of the post-test. While no students used Preparator on the pre-test, two $(33 \%)$ did so on the post-test (native speakers $=70 \%$ ). Pre-test to 
post-test use of Disarmer increased from one student (17\%) to four students $(67 \%)$, a movement towards target-like performance (native speakers $=80 \%$ ). An increase in the use of Acknowledgement of imposition from pre-test $(0 \%)$ to three students $(50 \%)$ on the post-test was also consistent with a shift towards target pragmatic norms (native speakers $=70 \%$ ). Grounder $($ pre-test $=100 \%$, post-test $=100 \%$ ) and Appreciation use (pre-test $=83 \%$, post-test $=100 \%$ ) prior to and after study abroad were consistent with target-like use (native speakers $=100 \%$ ).

On the Exchanging a Bus Ticket scenario, Table 8.5 shows that the students increased their use of four external mitigation strategies on the post-test. Each of these increases was again consistent with movement towards more targetlike request behaviour. The students increased their use of Preparator from pretest $(0 \%)$ to two students $(33 \%)$ on the post-test (native speakers $=30 \%$ ). Although one student (17\%) used Acknowledgement of imposition on the pretest, three $(50 \%)$ did so on the post-test (native speakers $=40 \%$ ). The students also increased their use of Disarmer from one $(17 \%)$ on the pre-test to four $(67 \%)$ on the post-test (native speakers $=80 \%)$. Pre-test to post-test use of Grounder increased from four $(67 \%)$ on the pre-test to all six $(100 \%)$ on the post-test, again representing a shift towards more target pragmatic norms (native speakers $=100 \%$ ). Examples $(5)$ and $(6)$ demonstrate the shift towards greater use of external mitigation on the post-tests:

(5) Preparator use on post-test Slower Speech scenario (Katie)

Hola, profesor. Disculpe, le quería hacer una consulta.

$\mathrm{Hi}$, professor. Excuse me, I wanted to ask you a question.

(6) Acknowledgement of Imposition use on post-test Paper Extension scenario (Heather)

Claro ... entiendo ... pero creo que este viaje sería una buena experencia para mí.

Of course ... I understand ... but I think that this trip would be a good experience for me.

Turning to request perspective orientation, the distribution of request perspective verbs for the four scenarios is presented in Table 8.6.

Four request perspectives were observed in the data: speaker-oriented, hearer-oriented, impersonal and elliptical requests. Results indicate that the students shifted their request behaviour from a strong preference for speakeroriented requests to a greater use of hearer-oriented requests after study abroad. In the Requesting Something to Drink scenario, for example, all six students used speaker-oriented verbs on the pre-test. At the time of the post-test, there was one $(17 \%)$ who continued to use a speaker-oriented request, while four $(67 \%)$ adopted hearer-oriented request forms and one $(17 \%)$ used an elliptical request. The observable shift from speaker-oriented to hearer-oriented and 
Table 8.6 Comparison of use of request perspective for study abroad students and native speakers of Spanish

Study abroad students

$\begin{array}{llll}\overline{\text { Pre-test }} & \text { Post-test } & & \text { Spanish native speakers } \\ & n(\%) & & n(\%)\end{array}$

\begin{tabular}{llll}
\hline $\begin{array}{l}\text { Requesting Something to Drink scenario } \\
\text { Hearer-oriented }\end{array}$ & $0(0 \%)$ & $4(67 \%)$ & $6(60 \%)$ \\
Speaker-oriented & $6(100 \%)$ & $1(17 \%)$ & $1(10 \%)$ \\
Impersonal & $0(0 \%)$ & $0(0 \%)$ & $0(0 \%)$ \\
Elliptical & $0(0 \%)$ & $1(17 \%)$ & $3(30 \%)$ \\
Paper Extension scenario & & & \\
Hearer-oriented & $0(0 \%)$ & $5(83 \%)$ & $8(80 \%)$ \\
Speaker-oriented & $5(83 \%)$ & $1(17 \%)$ & $2(20 \%)$ \\
Impersonal & $1(17 \%)$ & $0(0 \%)$ & $0(0 \%)$ \\
Slower Speech scenario & & & \\
Hearer-oriented & $2(33 \%)$ & $4(67 \%)$ & $10(100 \%)$ \\
Speaker-oriented & $0(0 \%)$ & $0(0 \%)$ & $0(0 \%)$ \\
Impersonal & $4(67 \%)$ & $2(33 \%)$ & $0(0 \%)$ \\
Exchanging a Bus Ticket scenario & & & \\
Hearer-oriented & $0(0 \%)$ & $2(33 \%)$ & $3(30 \%)$ \\
Speaker-oriented & $5(83 \%)$ & $1(17 \%)$ & $4(30 \%)$ \\
Impersonal & $1(17 \%)$ & $3(50 \%)$ & $3(30 \%)$ \\
\hline \hline
\end{tabular}

elliptical requests over time was indicative of movement towards the target norm, given that $90 \%$ of the native speakers used either hearer-oriented or elliptical requests in the same scenario.

In the Paper Extension scenario, the students again increased their use of hearer-oriented requests during study abroad. In this scenario, five out of the six (83\%) used speaker-oriented requests on the pre-test. At the time of the post-test, in contrast, five participants $(83 \%)$ shifted their request behaviour towards hearer-oriented forms. This general pattern of development represented a movement towards target-like performance, given that $80 \%$ of the native speakers of Spanish used hearer-oriented verbs in the same request scenario.

In the Slower Speech scenario, the group also increased their use of heareroriented requests from pre-test to post-test. At the time of the pre-test, four out of the six students (67\%) used impersonal requests, while the remaining two (33\%) used hearer-oriented requests. On the post-test, four out of the six students (67\%) used hearer-oriented requests, while the remaining two (33\%) used impersonal requests. The shift towards greater use of hearer-oriented strategies on the post-test and less reliance on impersonal requests was consistent with 
movement in the direction of target-like norms, given that $100 \%$ of the Spanish speakers used hearer-oriented requests in the same scenario.

With regard to the Exchanging a Bus Ticket scenario, Table 8.6 shows that the students again shifted their reliance from speaker-oriented request forms on the pre-test to preference for a combination of request perspectives on the posttest. Five out of the six students $(83 \%)$ used speaker-oriented requests on the pre-test. On the post-test, three out of the six (50\%) used either hearer-oriented or speaker-oriented requests, while the remaining three $(50 \%)$ adopted an impersonal request perspective. In requesting to exchange their bus ticket, the native speakers also used a combination of hearer-oriented (30\%), speaker-oriented $(40 \%)$ and impersonal $(30 \%)$ request strategies. Examples (7) and (8) demonstrate the L2 learners' gradual shift from speaker-oriented to hearer-oriented requests:

(7) Requesting Something to Drink scenario

Hola, ¿Puedo tener un café por favor? (Anna, Pre-test)

$\mathrm{Hi}$, can I have a coffee please?

Hola, ¿me darías un café por favor? (Anna, Post-test)

$\mathrm{Hi}$, could you give me a coffee please.

(8) Paper Extension scenario

Hola, doctor Blanco...PPedo entregar el ensayo el lunes? (Heather, Pre-test)

Hi, Doctor Blanco... Can I turn in my paper Monday?

Buenas tardes, doctor Blanco... ¿usted me daría una extensión en el informe por favor? (Heather, Post-test)

Good afternoon, Doctor Blanco. Would you please give me an extension on my paper?

Research Question 2: What do the students' journal entries and interviews reveal about their learning of requests during the short-term study abroad experience?

Journal entries and interviews provide further insight into how the students viewed their L2 pragmatic development. Results are again presented first for internal mitigation, then for external mitigation and finally for request perspective. An examination of the journal entries and interviews suggests that the students became more aware of how to use internal mitigation in their requests. Four students reported learning how to use indirect request strategies with the imperfect past tense (e.g. Quería saber si ... 'I wanted to know if'). Patrick, for example, noted that the native speakers used the imperfect past tense to demonstrate politeness or hesitation when making a request. All six students also reported learning how to use the conditional tense to be polite (e.g. ¿Me daría una extensión en el informe? 'Would you give an extension on the 
paper?') As a result of the language practice, Heather reported that she paid more attention to the relationship between context and language use. She described how the language practice tasks contributed to her understanding of how important it was to tailor language use to an interlocutor, and also to the context and nature of her request. Katie also attributed her L2 pragmatic development to the pre-departure pragmatic instruction and the language practice tasks that she performed during study abroad. She was enthusiastic in describing how she now knew how to use the conditional tense and the imperfect past tense to make a polite request. Sam reported how the language tasks in which he had to compare his target language production with that of a native speaker made him aware of his own language use. Patrick also viewed the language practice tasks as beneficial for his L2 development. He reported that the tasks encouraged him to become conscious of and notice the language that was used in Buenos Aires. He was then able to change his own L2 production to make it more similar to target behaviour.

The journal entries and interviews also provide insights into how the students perceived the use of the politeness marker por favor during study abroad. Four students reported noticing that the native speakers did not use por favor in some of the request scenarios for the language practice tasks. Further, the participants observed that the Spanish speakers often substituted the politeness marker with other linguistic forms of mitigation. In the first language task, exchanging a jacket without the receipt, Katie noted that one of her native speakers was much more direct than she was, and in fact did not use por favor at all in some of the request sequences. Katie stated that although she viewed this speech act as appropriate in Spanish, it might be considered rude or offensive in English.

Journal entries and interviews also revealed that the students also became more attentive to the use of the address terms vos and usted in Argentina. Anna reported that she had a better understanding of how to ask questions in formal and informal situations and when to address a person with vos and when to speak to him or her using usted. Patrick also stated that the language practice tasks gave him a clear idea of how a native speaker might address an interlocutor. In the second language practice task (asking for a doctor's appointment on the phone) Patrick reported that after comparing his transcript with that of a native speaker, he noticed that he should have used the more formal address form usted when making the appointment.

The students also became more aware of target-like use of external mitigation strategies over time. Five out of the six reported that the language practice had a positive effect on their understanding of this aspect of their request performance. In the first language practice task (Exchanging a Jacket without the Receipt), three students noticed that the native speakers began their requests with a clear explanation of the problem and what was needed from 
the store clerk. The students noted that this approach was much more effective than their own requests, which often lacked sufficient background information. In the fifth language task (Asking a Professor to Reschedule an Exam), several students reported recognizing the importance of acknowledging that such a request might represent an imposition on the interlocutor. In describing how her native speaker asked the professor to reschedule the exam, Jennifer noted that he was more convincing in that he first asked the professor if he could ask him a question. The native speaker informant then gave a clear explanation and rationale for the request while also acknowledging that he understood that granting such a request would be an exception and potential inconvenience to him.

All six students reported focusing on using more hearer-oriented than speaker-oriented requests as a result of the language practice. Sam described how he learned to interact with native speakers in Spanish, for example, and how it was often more appropriate to use a hearer-oriented request when asking for an item at a store or restaurant rather than a speaker-oriented request. Heather also reported drawing on what was discussed in class about appropriate target-like request strategies when she spoke with her host mother and other native speakers, such as when to use a hearer-oriented versus a speaker-oriented request. Likewise, Grace recalled her surprise at learning during pre-departure instruction that some of the request strategies that she had previously used (e.g. ¿Puedo tener ...? 'Can I have?') were inappropriate in Spanish. In one of her journal entries, Grace described how she began to notice that native speakers of Spanish indeed used other forms to make their requests (e.g., ¿Me daría ...? 'Could you give me?').

Journal entries and interviews suggest that the targeted feedback that the students received from the researcher was also an important factor in their pragmatic development. They explained that by drawing their attention to target-like request behaviour, the researcher encouraged them to reflect on their L2 production during the language practice tasks and seek means to improve their performance. In other words, as Swain (2000) has suggested about the importance of feedback during interaction, the L2 learners were made aware of and paid more attention to the relationships between linguistic forms and their function.

\section{Discussion}

The aim of the present investigation was to measure the impact of exposure to language practice prior to and during study abroad on L2 learners' request performance. Results from four pre-test and post-test role plays indicate that the students increased their use of target-like request strategies over time. Further, an examination of the students' journal entries and interviews suggests 
that the students became more aware of the pragmatic norms of the host culture. Journal entries and interviews also show that the students had frequent opportunities to use their Spanish across a wide range of communicative contexts. Each participant reported making requests in convenience stores, shopping centres, bars, cafés, restaurants and kioscos. The L2 learners also made requests when talking with tour guides on academic-cultural excursions and with their respective host families. The role plays, journals and interviews, when taken together, suggest that the treatment given to the students prior to and during study abroad did indeed have a positive effect on their L2 pragmatic development. Kasper and Rose (2002) have argued that L2 learners shift from direct to indirect requests as their proficiency in the target language increases. This group's results are consistent with these findings. The participants in this study increased their use of verbal mitigation on each of the four request scenarios. With the exception of the Requesting Something to Drink scenario, their use of the conditional and imperfect forms on the post-tests was similar to that of the native speakers from Buenos Aires. Because this scenario represented a low-imposition request with a 25 -year-old interlocutor, the participants' overuse of verbal mitigation suggests that they were not aware that the sociolinguistic context did not require them to mitigate their requests. In this scenario, the native speakers of Spanish were in fact much more direct than were the L2 learners at the time of the post-test, with $70 \%$ of them not using verbal mitigation to ask for their drink. Using a written request production questionnaire, Shively and Cohen (2008) found that after one semester abroad, their students became more target-like by increasing their use of verbal mitigation with conditional forms. Their students did not, however, demonstrate a similar increase in verbal mitigation with the imperfect past tense. Because the L2 learners in this study did not improve this aspect of their request behaviour suggests that explicit instruction might be useful for drawing their attention to this linguistic form as a resource for mitigation.

Previous studies have concluded that less proficient L2 learners often overuse politeness markers to mitigate their requests because of their transparent meaning and function and the students' own desire to be polite in the target language (Barron 2003; Pinto 2005). As L2 learners become more proficient, their dependence on the politeness marker decreases as their repertoire of strategies to mitigate their requests begins to increase (Cole and Anderson 2001; Barron 2003; Pinto 2005; Félix-Brasdefer 2007; Bataller 2008). Although a general overuse of the politeness marker por favor was observed in the Requesting Something to Drink scenario both before and after study abroad, no similar pattern was found in the other request scenarios. In Requesting Something to Drink, a short, routine and low-imposition request scenario, it appears that the students did not recognize that the use of the politeness marker was not critical to successful interaction with their interlocutor. 
The remaining request scenarios, by contrast, represented mid- and highimposition scenarios. Each of these scenarios required significantly greater interaction between the student and the interlocutor. The L2 learners therefore found themselves with more opportunities to use other forms of internal and external mitigation in these scenarios. Using role plays, Bataller (2008) also found that her students overused the politeness marker por favor during some service encounter exchanges. Shively and Cohen (2008), on the other hand, discovered that their study abroad participants underused the politeness marker in three request scenarios on a written request production questionnaire. The researchers concluded that the students had gone too far in adopting other strategies to mitigate their requests. The differing nature of the assessment measures used in these two studies (role plays versus written production questionnaire) may account for these disparate findings.

As for external mitigation, examination of the request scenarios revealed that the students used fewer strategies than did the native speakers of Spanish at the time of the pre-test. This finding confirms previous studies on L2 pragmatics (Schauer 2004; Félix-Brasdefer 2007; Schauer 2007; Shively and Cohen 2008). At the time of the post-test, however, the students began to incorporate more target-like external mitigation. They increased their use of three out of the six strategies: Acknowledgement of imposition, Disarmer and Preparator. Their use of Grounder and Appreciation was similar to the target norm on the pre-test and post-test, a finding that seems to follow the developmental path outlined in Félix-Brasdefer (2007). Whereas his beginning and intermediate Spanish L2 learners overused Grounders, his advanced learners controlled a wider range of external mitigation strategies.

The L2 learners in this study also adopted a more target-like request perspective during study abroad. They shifted from reliance on speakeroriented requests to greater use of hearer-oriented requests. L1 transfer might account for the group's extensive use of speaker-oriented requests at the time of the pre-test. Previous researchers have affirmed that L1 English speakers have a preference for speaker-oriented requests, whereas L1 Spanish speakers prefer hearer-oriented request strategies (Pinto 2005; Félix-Brasdefer 2007; Shively and Cohen 2008; Shively 2011). Shively and Cohen (2008) discovered that their study abroad learners continued to use speaker-oriented requests verbs even after a semester of study abroad. Shively (2011), however, reported that students who received pragmatic instruction as part of their study abroad experience were able to shift from speaker- to hearer-oriented and elliptical requests in service encounter exchanges.

Although the L2 learners in this study became more target-like in their request behaviour, there were some aspects of their pragmatic production that remained unchanged at the time of the post-test. Five students continued to overuse the politeness marker por favor on the Requesting Something to Drink 
scenario, for example. While two students used a non-target-like impersonal request perspective on the Slower Speech scenario, three did so on the Exchanging a Bus Ticket scenario. External mitigation was underused on some request scenarios. The overuse of verbal mitigation on the Requesting Something to Drink scenario suggests that, despite the low-imposition nature of the request, the study abroad students did not notice or understand that native speakers do not use verbal mitigation in this context. At the time of the post-test, one student used an elliptical request on the Requesting Something to Drink scenario, while the native speakers used elliptical requests $30 \%$ of the time - a finding consistent with previous research (Bataller 2008; Bataller 2010; Shively 2011). Taken together, results indicate that these aspects of request performance merit further practice.

\section{Conclusion}

The targeted language practice given to the students prior to and during the short-term study abroad experience had a positive impact on their L2 pragmatic development. All six students increased their use of target-like request strategies. Journal entries and interviews with the researcher also indicated that the students became more aware of appropriate target-like request behaviour. In their journals and interviews, the students also attributed their L2 pragmatic development to three additional sources: to interactions with host families and other native speakers, to their participation in service encounter exchanges, and to the targeted feedback given to them by the researcher.

As a result of the language practice, the students paid more attention to their L2 development during study abroad. The explicit instruction given to students during pre-departure orientation was successful in drawing their attention (Schmidt 2001) to target-like request behaviour and the pragmatic norms of the host culture. Pre-departure language practice under the guidance of the researcher provided the students with opportunities to transform their declarative knowledge about pragmatics into procedural knowledge. In addition, the five language practice tasks assigned to the students while in Argentina increased their opportunities for L2 production, something often claimed to be an essential component of L2 learning (Swain 2000), and encouraged them to make progress towards automatisation. The language tasks also provided the students with opportunities for social interaction with native speakers. In comparing their request strategies with those of the native speakers, the L2 learners' attention was drawn to differences between their, at times, non-targetlike L2 use and native-like pragmatic norms. The targeted feedback that the students received from the researcher was again successful in drawing their attention to important aspects of pragmatics in the context of their experience in Argentina. The journal entries represented another important feature of the 
language practice, which allowed the students to reflect on their own L2 pragmatic development while becoming more aware of target-like request behaviour.

In order to gain a better understanding of the effect of exposure to language practice prior to and during study abroad, researchers could include a control group consisting of L2 learners who do not receive a treatment during their time in the host culture. Researchers could also examine whether there is a relationship between L2 pragmatic development and motivation. Finally, SLA researchers and language educators could also collaborate to develop a more extensive pragmatic intervention for study abroad consisting of more speech acts and speech act scenarios containing a wider range of social and contextual variables, and one way of undertaking this might be to investigate the impact of an online course in language and culture strategies as part of the study abroad experience.

In sum, all six students increased their use of target-like request strategies during a six-week study abroad experience in Argentina. Journal entries and interviews also revealed that the students became more aware of the pragmatic norms of the host culture. The results affirm that study abroad programmes should consider providing students with a pragmatic intervention prior to and during study abroad that maximizes their target language practice. This in turn empowers them with language and culture strategies to have a more successful linguistic experience while in-country. Some researchers, for example, advocate the creation of a required one-credit course for study abroad students that would give them explicit instruction in the use of target language communication strategies (Cohen and Shively 2007; DeKeyser 2007). Furthermore, in order to maximise the potential role of language practice during study abroad, DeKeyser (2007) argues that study abroad programmes must also be more thoughtful about what happens upon returning from abroad. Study abroad staff should create opportunities for returning students to expand on their intercultural experience. Programme staff and language instructors could offer poststudy abroad sessions featuring language practice and reflection activities about the study abroad experience. Further, students could be encouraged to participate in online communities from the target culture and seek out target language communities at home (Shively 2010). Because of the increasing number of students participating in short- and long-term study abroad, it is important that our profession prepare L2 learners for a successful experience abroad which should include an active role for language practice prior to, during and after study abroad. 


\section{Appendix 8.A Sample Language Practice Tasks}

Exchanging a New Jacket. Imagine that you bought a jacket at a department store in downtown Buenos Aires during the weekend. After about a week you want to use your new jacket for the first time, but you notice that it has a stain on it. You return to the department store in order to exchange the jacket. You cannot find your receipt. A woman working at the counter greets you and asks what you need. She is about 30 years of age. Explain to her that you bought the jacket this past weekend, that it has a stain on it and that you would like to exchange it even though you do not have the receipt. You have 60 seconds to prepare and 60 seconds to speak.

Rescheduling an Exam. You are studying Spanish in Buenos Aires and would like to watch the second round 2014 World Cup match between Argentina and Switzerland. You and your classmates would like to watch the match, but your Spanish instructor, Professor Claudia Bedoya, has scheduled an exam at the same time as the match. Your classmates have asked you to speak to the instructor on their behalf to ask if she will reschedule the exam. You approach Professor Bedoya to explain the situation and ask about rescheduling the exam, but she is reluctant to do so. After Professor Beyoda expresses her reluctance, convince her that it is in the best interest of the class for her to reschedule the exam so that the students can watch the World Cup match between Argentina and Switzerland. You have 60 seconds to prepare and 70 seconds to speak. 


\section{Appendix 8.B Pre-test and Post-test Role-play Scenarios}

Asking a Professor for a Paper Extension. You find a bargain airfare for this weekend, which you want to make use of in order to visit good friends in Córdoba. But in order for you to take advantage of this great airfare price, you need to ask your professor, Dr Blanco, who is about 45 years old, for an extension on a paper that you were going to work on this weekend, and which is due on Monday.

Asking a Professor to Speak Slower. You are enrolled in a required history class taught in Spanish for study abroad students. The fourth class session of the summer programme has ended and you are frustrated. Your professor, Dr García, has once again spoken too fast for you to understand. You find out that your classmates are also having the same problem. So, you get up your courage, approach him after class and request that he speak slower and clearer. Dr García is about 50 years old.

Exchanging a Ticket at a Bus Terminal. Before your classes this morning, you went to the bus terminal at Retiro to purchase a bus ticket for a long weekend trip to Mendoza. After classes, you check your bus ticket and realise that you bought your ticket for the incorrect weekend. You return to Retiro to see if you can exchange your ticket for a new ticket with new departure and return dates. You approach the ticket counter. A gentleman working at the counter greets you and asks what you need. He is about 40 years of age. 


\title{
Appendix 8.C Coding Scheme for Requests
}

\author{
Coding category \\ Example from student and native-speaker data \\ Internal mitigation strategies \\ Conditional \\ Buenas tardes Doctor García ... ¿podría hablar un poco más \\ despacio en clase? \\ Good afternoon Doctor García. Could you speak a little slower in \\ class? \\ Imperfect \\ (Grace, Post-test: Slower Speech scenario) \\ Disculpe Doctor Blanco ... yo le quería pedir si me daría una \\ extensión para terminar mi informe. \\ Excuse me Doctor Blanco. I wanted to ask you if you could give \\ me an extension to finish my paper. \\ (Native speaker: Paper Extension scenario) \\ Politeness marker por favor \\ ¿Me das un café por favor? \\ Can you give me a coffee please? \\ (Heather, Post-test: Requesting Something to Drink scenario)
}

External mitigation
strategies
Preparator

Grounder

Disarmer

Buenas tardes profesor ... disculpe ... . Tiene usted un segundo? Le quería hacer una consulta.

Good afternoon professor. . . excuse me ... Do you have a second? I wanted to ask you a question.

(Native speaker: Paper Extension scenario)

Mire .... lo que pasó es que compré un boleto para ir a Mendoza ... este fin de semana, pero en realidad yo necesito un boleto para otro fin de semana ...

Look, what happened is that I bought a ticket to go to Mendoza ... for this weekend, but the truth is that I need a ticket for another weekend ...

(Heather, Post-test: Exchanging a Bus Ticket scenario)

Entonces, entiendo que tal vez pueda haber algún recargo o ... algún cambio de asiento y demás pero ... necesito viajar en esa fecha.

So, I understand that there might be a charge ... or a seat change and what not but... I need to travel on that date.

(Native speaker: Exchanging a Bus Ticket scenario) 
(cont.)

\begin{tabular}{|c|c|}
\hline Coding category & Example from student and native-speaker data \\
\hline Imposition minimiser & $\begin{array}{l}\text { Entiendo ... si no me puede dar la extensión hasta el viernes ... } \\
\text { ¿está bien el miércoles? } \\
\text { Entiendo ... if you can't give an extension until Friday, is } \\
\text { Wednesday OK? } \\
\text { (Anna, Post-test: Paper Extension scenario) }\end{array}$ \\
\hline $\begin{array}{l}\text { Acknowledgement of } \\
\text { imposition }\end{array}$ & $\begin{array}{l}\text { Entiendo que sería como una excepción que estaría haciendo } \\
\text { conmigo pero la verdad es que lo agradecería mucho si lo } \\
\text { pudiera hacer. } \\
\text { I understand that it would be an exception that you would be } \\
\text { making for me, but the truth is that I would appreciate it if you } \\
\text { could do that for me. } \\
\text { (Native speaker: Paper Extension scenario) }\end{array}$ \\
\hline Appreciation & $\begin{array}{l}\text { Gracias profesor. Se lo agradezco muchísimo. } \\
\text { Thanks professor. I appreciate it so much. } \\
\text { (Grace, Post-test: Paper Extension scenario) }\end{array}$ \\
\hline Requests perspective & \\
\hline Hearer-oriented & $\begin{array}{l}\text { ¿Podría usted hablar más despacio en clase? } \\
\text { Could you speak slower in class? } \\
\text { (Sam, Post-test: Slower Speech scenario) }\end{array}$ \\
\hline Speaker-oriented & $\begin{array}{l}\text { Hola Doctor Blanco. ¿Puedo tener más tiempo para entregar mi } \\
\text { ensayo? } \\
\text { Hi Doctor Blanco. Can I have more time to turn in my paper? } \\
\text { (Katie, Pre-test: Paper Extension scenario) }\end{array}$ \\
\hline Impersonal & $\begin{array}{l}\text { Hola, buenas tardes Doctor García ... ¿Es posible hablar más } \\
\text { despacio? } \\
\text { Hello. Good afternoon Doctor García. Is it possible to speak } \\
\text { slower? } \\
\text { (Ben, Pre-test: Slower Speech scenario) }\end{array}$ \\
\hline Elliptical & $\begin{array}{l}\text { Un café, por favor. } \\
\text { A coffee, please. } \\
\text { (Anna, Post-test: Requesting a Drink Scenario) }\end{array}$ \\
\hline
\end{tabular}

\section{REFERENCES}

Allen, H. W. 2010. 'Interactive contact during study abroad as linguistic affordance: Myth or reality?', Frontiers: The Interdisciplinary Journal of Study Abroad 19: $1-26$.

Barron, A. 2003. Acquisition in Interlanguage Pragmatics: Learning How to Do Things with Words in a Study Abroad Context. Amsterdam: John Benjamins.

2006. 'Learning to say you in German: The acquisition of sociolinguistic competence in a study abroad context', in DuFon, M. A. and Churchill, E. (eds.), Language Learners in Study Abroad Contexts. Clevedon: Multilingual Matters, 59-88.

Bataller, R. 2008. 'Pragmatic development in the study abroad setting: Requesting a service in Spanish', unpublished doctoral dissertation, University of Iowa, Iowa City. 
2010. 'Making a request for a service in Spanish: Pragmatic development in the study abroad setting', Foreign Language Annals 43: 160-175.

Bataller, R. and Shively, R. L. 2011. 'Roleplays and naturalistic data in interlanguage pragmatic research: Service encounters during study abroad', Journal of Linguistics and Language Teaching 2: 15-50.

Blum-Kulka, S., House, J. and Kasper, G. 1989. 'The CCSARP coding manual', in Blum-Kulka, S., House, J. and Kasper, G. (eds.), Cross-cultural Pragmatics: Requests and Apologies. Norwood, NJ: Ablex, 273-294.

Brown, P. and Levinson, S. 1987. Politeness: Some Universals in Language Use. Cambridge: Cambridge University Press.

Canale, M. and Swain, M. 1980. 'Theoretical bases of communicative approaches to second language teaching and testing', Applied Linguistics 1: 1-47.

Castañeda, M. E. and Zirger, M. L. 2011. 'Making the most of the new study abroad: Social capital and the short-term sojourn', Foreign Language Annals 44: 544-564.

Cohen, A. D. and Shively, R. L. 2007. 'Acquisition of requests and apologies in Spanish and French: Impact of study abroad and strategy-building intervention', Modern Language Journal 91: 189-212.

Cole, S. and Anderson, A. 2001. 'Requests by young Japanese: A longitudinal study', The Language Teacher Online 25. Available online at: www.jaltpublications.org [Accessed 28 July 2012].

DeKeyser, R. 2007. 'Study abroad as foreign language practice', in DeKeyser, R. M. (ed.), Practice in a Second Language: Perspectives from Applied Linguistics and Cognitive Psychology. Cambridge: Cambridge University Press, 208-226.

Dufon, M. A. 1999. 'The acquisition of linguistic politeness in Indonesian by sojourners in naturalistic interactions', unpublished doctoral dissertation, University of Hawai'i at Manoa, Honolulu.

Félix-Brasdefer, J. C. 2007. 'Pragmatic development in the Spanish as a FL classroom: A cross-sectional study of learner requests', Intercultural Pragmatics 4: 253-286.

2010. 'Data collection methods in speech act performance: DCTs, role plays, and verbal reports', in Martínez-Flor, A. and Usó-Juan, E. (eds.), Speech Act Performance: Theoretical, Empirical, and Methodological Issues. Amsterdam: John Benjamins, 41-56.

Hernández, T. A. 2010. 'The relationship among motivation, interaction, and the development of second language oral proficiency in a study abroad context', Modern Language Journal 94: 600-617.

2016. 'Short-term study abroad: Perspectives on speaking gains and language contact', Applied Language Learning 26: 65-89.

Hoffman-Hicks, S. D. 1999. 'The longitudinal development of French foreign language pragmatic competence: Evidence from study abroad participants', unpublished doctoral dissertation, Indiana University, Bloomington.

Kasper, G. and Rose, K. R. 2002. Pragmatic Development in a Second Language. Malden, MA: Wiley-Blackwell.

Kinginger, C. 2008. 'Language learning in study abroad: Case studies of Americans in France', Modern Language Journal 92: 1-131.

Magnan, S. S. and Back, M. 2006. 'Requesting help in French: Developing pragmatic features during study abroad', in Wilkinson, S. (ed.), Insights from Study Abroad for Language Programs. Boston: Heinle, 22-44. 
2007. 'Social interaction and linguistic gain during study abroad', Foreign Language Annals 40: 43-64.

Martínez-Flor, A. and Usó-Juan, E. 2006. 'A comprehensive pedagogical framework to develop pragmatics in the foreign language classroom: The 6Rs approach', Applied Language Learning 16: 39-64.

Mendelson, V. G. 2004. 'Hindsight is 20/20: Student perceptions of language learning and the study abroad experience', Frontiers: The Interdisciplinary Journal of Study Abroad 10: 43-63.

Pellegrino, V. A. 1998. 'Student perspectives on language learning in a study abroad context', Frontiers: The Interdisciplinary Journal of Study Abroad 4: 91-120.

Pinto, D. R. 2005. 'The acquisition of requests by second language learners of Spanish', Spanish in Context 2: 1-27.

Ren, W. 2014. 'A longitudinal investigation into L2 learners' cognitive processes during study abroad', Applied Linguistics 35: 575-594.

Schauer, G. 2004. 'May you speak louder maybe? Interlanguage pragmatic development in requests', in Foster-Cohen, S. and Sharwood-Smith, M. (eds.), EUROSLA Yearbook, Vol. 4. Amsterdam: John Benjamins, 253-273.

2007. 'Finding the right words in the study abroad context: The development of German learners' use of external modifiers in English', Intercultural Pragmatics 4: 193-220.

2009. Interlanguage Pragmatic Development: The Study Abroad Context. London: Continuum.

Schmidt, R. 2001. 'Attention', in Robinson, P. (ed.), Cognition and Second Language Instruction. New York: Cambridge University Press, 3-33.

Shively, R. L. 2010. 'From the virtual world to the real world: A model of pragmatics instruction for study abroad', Foreign Language Annals 43: 105-137.

2011. 'L2 pragmatic development in study abroad: A longitudinal study of Spanish service encounters', Journal of Pragmatics 43: 1818-1835.

2013. 'Out-of-class interaction during study abroad: Service encounters in Spain', Spanish in Context 10: 53-91.

Shively, R. L. and Cohen, A. D. 2008. 'Development of Spanish requests and apologies during study abroad', Íkala, revista de lenguaje y cultura 13: 53-118.

Swain, M. 2000. 'The output hypothesis and beyond: Mediating acquisition through collaborative dialogue', in Lantolf, J. (ed.), Sociocultural Theory and Second Language Learning. Oxford: Oxford University Press, 97-114.

Usó-Juan, E. 2010. ‘A sociopragmatic approach', in Martínez-Flor, A. and Usó-Juan, E. (eds.), Speech Act Performance: Theoretical, Empirical and Methodological Issues. Amsterdam: John Benjamins, 237-256.

Wilkinson, S. 2000. 'On the nature of immersion during study abroad: Some participants' perspectives', Frontiers: The Interdisciplinary Journal of Study Abroad 4: 121-138. 